\title{
Bithionol inhibits ovarian cancer cell growth In Vitro - studies on mechanism(s) of action
}

\author{
Vijayalakshmi N Ayyagari and Laurent Brard ${ }^{*}$
}

\begin{abstract}
Background: Drug resistance is a cause of ovarian cancer recurrence and low overall survival rates. There is a need for more effective treatment approaches because the development of new drug is expensive and time consuming. Alternatively, the concept of 'drug repurposing' is promising. We focused on Bithionol (BT), a clinically approved anti-parasitic drug as an anti-ovarian cancer drug. BT has previously been shown to inhibit solid tumor growth in several preclinical cancer models. A better understanding of the anti-tumor effects and mechanism(s) of action of BT in ovarian cancer cells is essential for further exploring its therapeutic potential against ovarian cancer.

Methods: The cytotoxic effects of BT against a panel of ovarian cancer cell lines were determined by Presto Blue cell viability assay. Markers of apoptosis such as caspases 3/7, CPARP induction, nuclear condensation and mitochondrial transmembrane depolarization were assessed using microscopic, FACS and immunoblotting methods. Mechanism(s) of action of BT such as cell cycle arrest, reactive oxygen species (ROS) generation, autotaxin (ATX) inhibition and effects on MAPK and NF-kB signalling were determined by FACS analysis, immunoblotting and colorimetric methods.

Results: BT caused dose dependent cytotoxicity against all ovarian cancer cell lines tested with $\mathrm{IC}_{50}$ values ranging from $19 \mu \mathrm{M}-60 \mu \mathrm{M}$. Cisplatin-resistant variants of A2780 and IGROV-1 have shown almost similar $\mathrm{IC}_{50}$ values compared to their sensitive counterparts. Apoptotic cell death was shown by expression of caspases 3/7, CPARP, loss of mitochondrial potential, nuclear condensation, and up-regulation of p38 and reduced expression of pAkt, pNF-kB, plkBa, XIAP, bcl-2 and bcl-xl. BT treatment resulted in cell cycle arrest at G1/M phase and increased ROS generation. Treatment with ascorbic acid resulted in partial restoration of cell viability. In addition, dose and time dependent inhibition of ATX was observed.

Conclusions: BT exhibits cytotoxic effects on various ovarian cancer cell lines regardless of their sensitivities to cisplatin. Cell death appears to be via caspases mediated apoptosis. The mechanisms of action appear to be partly via cell cycle arrest, ROS generation and inhibition of ATX. The present study provides preclinical data suggesting a potential therapeutic role for BT against recurrent ovarian cancer.
\end{abstract}

Keywords: Bithionol, Ovarian cancer cell lines, Apoptosis, Reactive oxygen species, Autotaxin

\section{Background}

Ovarian cancer accounts for $5 \%$ of cancer deaths among women in the United States and has the highest mortality rate of all gynecologic cancers [1]. The majority of women diagnosed with advanced ovarian cancer have a low overall survival [2]. Drug resistance is the key reason for ovarian cancer recurrence and poor overall survival [2-4]. Although most ovarian cancer patients $(70-80 \%)$

\footnotetext{
* Correspondence: Ibrard@siumed.edu

Division of Gynecologic Oncology; Department of Obstetrics and Gynecology, Southern Illinois University School of Medicine, Springfield, IL, USA
}

\section{Biomed Central}

initially respond to cytoreductive surgery and adjuvant paclitaxel and platinum-based chemotherapy, the majority will experience disease recurrence $[5,6]$. The response rate to current second-line or third-line (after interim non-platinum therapy) chemotherapy is less than 33\% due to the rise of resistance to these drugs [7-10]. Hence there is a need for more effective therapies and/or treatment approaches to overcome drug resistance.

New drug discovery demands enormous cost and time. An alternative approach is 'Drug Repurposing' wherein clinically approved drugs for one indication are re-explored 
for new applications. It is well known that many drugs exhibit polypharmacological properties, and hence can be explored for their ability to modulate new/alternate targets. 'Drug repurposing' is a cost effective alternative to new drug discovery as ADME and basic toxicity are already well established and can be immediately taken to Phase II/III clinical trials. However, in order to "repurpose" these drugs for novel targets/diseases, it is essential to first understand the basic biological action(s) and mechanism(s) of action in preclinical and animal models.

In our present study, we focused on Bithionol (2, 2' Sulfanediylbis (4, 6-dichlorophenol), a clinically approved anti-parasitic drug as an anti-ovarian cancer drug. Bithionol (BT) has received Food and Drug Administration approval as a second-line orally administered medication for the treatment of helminthic infection and has been safely dosed in humans [11]. All the details of toxicology and pharmacokinetic properties for BT are available (Toxnet, National library of medicine).

BT was shown to be an effective anti-cancer agent in preclinical models and is safe in non-cancer patients [11-13]. BT was shown to decrease tumor weight in a breast cancer model and reduced metastases of tumors initiated with A2058 melanoma cells [12]. BT was reported to reduce melanoma cell migration in a dosedependent fashion when assayed using in vitro cell migration and invasion systems [13]. Similar observations were reported in the case of breast and ovarian cancer cell lines [13]. BT was also reported to show an inhibitory effect on cervical cancer cell growth during in vitro screening [14]. These previous studies have proposed possible mechanisms of action of BT against cancer cells. Autotaxin (ATX) inhibition was proposed as a mechanism of action to decrease tumor in a pre-clinical melanoma model [12,13]. An additional mechanism was inhibition of NF-kB signalling via inhibition of $\mathrm{I} k \mathrm{~B} \alpha$ phosphorylation and caspase 3/7 induction [14]. Based on these significant observations, we seek a better understanding of the effect BT on ovarian cancer cell lines, and specifically on cisplatin-resistant cell lines.

The objective of the present study was to explore the cytotoxic effects of BT against ovarian cancer cell lines and to further delineate the cellular mechanism(s) of cytotoxicity. First, we studied the cytotoxic effect $\left(\mathrm{IC}_{50}\right.$ determination) against a panel of ovarian cancer cell lines exhibiting varying sensitivities to cisplatin. Secondly, we identified the type of cell death induced by BT i.e. apoptosis vs. necrosis, by assessment of caspase 3/7 activity and cleaved PARP expression (indicators of apoptosis) and lactate dehydrogenase activity (necrosis marker). In addition to these markers of cell death, we looked at other apoptosis-specific nuclear changes such as chromatin condensation as well as changes in mitochondrial potential.
To further delineate the mechanism(s) of action of BT, we focused on cell cycle, ROS generation, ATX inhibition, and pro-survival (pAkt, pNF-кB p65) and proapoptotic signalling (pP38 MAPK) markers. To assess whether BT-induced growth inhibition of the cells is mediated via alterations in cell cycle regulation, we evaluated the effect of BT on cell cycle distribution. Because the production of lethal levels of ROS has been suggested as a mechanism of action of various cytotoxic agents in cancer cells, we assessed effect of BT on ROS generation in ovarian cancer cell lines. To define the cellular response of ovarian cancer cell lines to treatment with $\mathrm{BT}$, we analysed the expression and/or activation of cellular markers that are hallmarks of pro-survival (pAkt, pNF-kB p65) and pro-apoptotic signalling (pP38 MAPK) in all cell lines. Finally, we studied the effect of BT on ATX secretion in ovarian cancer cell lines because BT has been shown to inhibit solid tumor growth in several preclinical cancer models by targeting autotaxin $[12,13]$.

\section{Methods \\ Cell lines and chemicals}

In order to assess the cytotoxic effects of BT, a panel of ovarian cancer cell lines exhibiting varying degrees of sensitivities to cisplatin was selected. OVACAR-3 and SKOV-3 are cisplatin-resistant whereas A2780 and IGROV-1 represent cisplatin-sensitive cell lines. Additionally, cisplatin-resistant variants of A2780 and IGROV-1 derived by in vitro selection with cisplatin were also tested for BT cytotoxicity. A2780, A2780-CDDP and IGROV-1, IGROV-1CDDP represents isogenic ovarian cancer cell line pairs consisting of a cisplatin-sensitive parental line and a stable cisplatin-resistant sub-line derived by in vitro selection with cisplatin.

Human ovarian carcinoma cell lines, OVACAR-3, SKOV-3 were obtained from Dr. McAsey (SIU School of Medicine, Springfield, IL). Isogenic ovarian cancer cell lines pairs, e.g., A2780/A2780-CDDP and IGROV-1/, IGROV-1CDDP were received as a generous gift from Dr. Brodsky (Brown University, Providence, RI). All cell lines were maintained in DMEM media (Sigma) supplemented with 10\% heat inactivated FBS (Hyclone), 100 IU penicillin (Mediatech) and $100 \mu \mathrm{g} / \mathrm{mL}$ streptomycin (Mediatech). All cell lines were cultured at $37^{\circ} \mathrm{C}$ in a humidified atmosphere at $5 \% \mathrm{CO}_{2}$. The cisplatin resistant variants A2780-CDDP and IGROV-1CDDP cells were treated with $3 \mu \mathrm{M}$ cisplatin every 3rd passage to maintain cisplatin resistance.

Bithionol (2, 2'-Sulfanediylbis (4, 6-dichlorophenol), Rhodamine-123 and propidium iodide were purchased from Sigma (St Louis, MO). Kinase inhibitors such as LY294002, SB203580 were purchased from Promega. All antibodies were purchased from Cell Signaling 
Technologies, (Danvers, MA). PrestoBlue ${ }^{\mathrm{Tm}}$ Cell Viability Reagent and ROS Dye - carboxy-H2DCFDA were purchased from Invitrogen (Carlsbad, CA).

\section{Cell viability assay}

Cell viability after BT treatment was determined by PrestoBlue cell viability reagent (Invitrogen) following the manufacturer's instructions. A $20 \mathrm{mM}$ stock of BT was prepared in DMSO and all the working dilutions were prepared in DMEM media. Ovarian cancer cell lines $\left(5 \times 10^{3}\right.$ cells/well $)$ were plated into 96 -well flat bottom plates (Corning, Inc., Corning, NY) and incubated for overnight. Cells were treated with different concentrations of BT ranging from $0.178 \mu \mathrm{M}$ to $400 \mu \mathrm{M}$ and further incubated for $48 \mathrm{hrs}$ or $72 \mathrm{hrs}$. At least 4-6 hrs before the end of treatment time, presto blue reagent was added and incubated for total of 48 or $72 \mathrm{hrs}$ and fluorescence measured (540 nm excitation/590 nm emissions). DMSO concentration was corrected to $1 \%$ in all wells. Vehicle treated control cells (media with 1\% DMSO) were considered as $100 \%$ viable against which treated cells were compared. Experiments were performed in triplicate. Data was expressed as mean $\pm \mathrm{SD}$ of triplicate experiments. Dose response curves to calculate $\mathrm{IC}_{50}$ values were plotted using Graph Pad Prism Software.

In order to ascertain role of ROS in BT induced cytotoxicity, we performed cell viability assays in the presence of an antioxidant, ascorbic acid. Cells were pretreated with $1 \mathrm{mM}$ ascorbic acid for $2 \mathrm{hrs}$ before addition of drug and further incubated for $48 \mathrm{hrs}$ with both BT $(50 \mu \mathrm{M}$ or $100 \mu \mathrm{M})$ and ascorbic acid $(1 \mathrm{mM})$. Restoration of cell viability was analyzed.

An additional cell viability assay was performed in order to assess role of p38 activation in BT induced cytotoxicity, in presence of the p38 inhibitor SB203580. Cells were treated with BT $(100 \mu \mathrm{M})$ in presence of $10 \mu \mathrm{M}$ SB203580 (non-toxic concentration) for $48 \mathrm{hrs}$ and cell viability was determined.

Lastly, to test if Akt inactivation is essential for drug sensitivity in ovarian cell lines treated with BT, a third cell viability assay was performed in order to see if additional pAkt inactivation would further enhance the effectiveness of BT. To look at this, we treated cells with BT in presence or absence of the pAkt inhibitor LY294002 $(10 \mu \mathrm{M})$.

Lactate dehydrogenase (LDH) assay (necrosis assessment) LDH release was measured using CytoTox-One Homogenous Membrane Integrity kit (Promega) following the manufacturer's instructions. Briefly, $10 \times 10^{3}$ cells/ $100 \mu \mathrm{L}$ were plated per well of the 96-well plate and treated with different concentrations of BT ranging from $12.5 \mu \mathrm{M}$ to $400 \mu \mathrm{M}$ for 6,24 and $48 \mathrm{hrs}$. Following treatment, $100 \mu \mathrm{L}$ of CytoTox-One reagent was added to each well. After incubation for $10 \mathrm{~min}$ at room temperature, the fluorescence intensity $(560 \mathrm{~nm}$ excitation/590 nm emission) was measured using a fluorescence microplate reader, Fluoroskan (Thermo Scientifics). A maximum LDH release control set (100\% LDH release) was generated as reference to calculate the actual \%LDH release from each sample. Percent of LDH released from vehicle treated (1\% DMSO media) control set is considered as $100 \%$ intact or $0 \% \mathrm{LDH}$ release. All samples were compared against vehicle control. Experiments were performed in triplicate. Data was expressed as mean \pm SD of triplicate experiments.

\section{Caspase $3 / 7$ assay (apoptosis assessment)}

Caspase 3/7 activity was measured using Caspase-Glo 3/7 assay kit from Promega, following the manufacturer's instructions. Briefly, $10 \times 10^{3}$ cells were plated per well of the 96-well plate and treated as described in the LDH assay (see above). Following treatment, Caspase-Glo 3/7 reagent was added and incubated for $30 \mathrm{~min}$. at room temperature. The luminescence intensity was measured using luminometer (luminoskan, Thermo Scientifics). Cells treated with vehicle (1\% DMSO media) were considered as control against which treated cells were compared. Experiments were performed in triplicate. Data was expressed as mean $\pm S D$ of triplicate experiments. In addition to homogenous caspase 3/7 assessment, we also analyzed expression of effector caspases, e.g., caspase- 3 and caspase7 via immunoblotting using specific antibodies against caspase 3 and 7 (see Western Blot Analysis below).

\section{Morphological studies to detect apoptosis}

To detect nuclear condensation indicative of apoptosis, NucBlue Live Cell Stain (Hoechst 33342) was used (Invitrogen, Carlsbad, CA). Hoechst 33342 is a cell-permeant nuclear counter-stain that emits blue fluorescence when bound to DNA [15]. It is excited by UV light and emits blue fluorescence at $460 \mathrm{~nm}$ when bound to DNA. To detect apoptotic specific nuclear changes, cells $\left(1 \times 10^{5}\right.$ cells) were seeded into 12 -well plate and treated with sub-cytotoxic BT at concentrations of $25 \mu \mathrm{M}, 50 \mu \mathrm{M}$ or $100 \mu \mathrm{M}$ for 6 or $24 \mathrm{hrs}$. Following treatment, cells were washed with PBS twice and fresh media containing Hoechst ( 2 drops $/ \mathrm{mL}$ of media) was added. Cells were incubated $15 \mathrm{~min}$. at $25^{\circ} \mathrm{C}$ and observed under fluorescent microscope. Representative images were taken with an inverted microscope (Olympus H4-100, CCD camera) and $20 \times$ objective. After morphological assessment by nuclear staining, extent of apoptosis was quantified using the TUNEL assay (described below).

\section{TUNEL assay}

DNA fragmentation was detected using the TiterTACS

2 TdT In Situ Colorimetric Apoptosis Detection Kit 
(Trevigen, Gaithersburg, MD) following the manufacturer's instructions. Briefly, cells were seeded at a density of $3 \times 10^{4}$ cells/well, into 96-well flat bottom plates and incubated for overnight. Cells were treated with BT as described previously. Following treatment, cells were washed and fixed followed by addition of labeled nucleotides and subsequent detection with HRP - HRP substrate (TACSSapphire) system. The absorbance was measured at $450 \mathrm{~nm}$ using a microplate reader, Multiskan (Thermo Scientifics).

\section{Mitochondrial transmembrane depolarization potential assay}

Mitochondrial transmembrane depolarization potential was determined by flow cytometry using Rhodamine123. Ovarian cancer cells $\left(1 \times 10^{6}\right)$ were seeded in a $100 \mathrm{~mm}^{2}$ culture dishes and treated with $50 \mu \mathrm{M}$ or $100 \mu \mathrm{M}$ BT for 6 or 24 hrs. Following treatment, cells were harvested by trypsinization, washed with PBS $(1 \times)$, and resuspended in fresh DMEM medium $\left(1 \times 10^{6}\right.$ cells $/ \mathrm{mL}$ ) containing rhodamine 123 at a concentration of $0.5 \mathrm{mg} / \mathrm{mL}$, and incubated for $30 \mathrm{~min}$. at $37^{\circ} \mathrm{C}$. The cells were washed twice with DPBS, re-suspended in DPBS and analyzed by flow cytometry (488 nm excitation/ $520 \mathrm{~nm}$ emission). Data was acquired on a BD Accuri C6 flow cytometer (BD Immunocytometry -Systems, San Jose, CA) and analyzed. Twenty thousand cells were analyzed for each sample. Appropriate gating was used to select standardized cell population.

\section{Cell-cycle analysis}

Cell cycle analysis was carried out by flow cytometry. Cells were seeded into $100 \mathrm{~mm}^{2}$ tissue culture dishes $\left(1 \times 10^{6}\right.$ cells/dish) and treated with $50 \mu \mathrm{M}$ BT for $24 \mathrm{hrs}$. At the end of the incubation period, detached cells were collected in $15 \mathrm{~mL}$ polypropylene centrifuge tubes along with the medium; culture dishes were washed once with PBS. Adherent cells were scraped off and combined in the same tube. After centrifugation (250 g, $5 \mathrm{~min}$.), cells were fixed by adding ice-cold $70 \%$ ethanol gradually. Following fixation, cells were stained with propidium iodide $(50 \mu \mathrm{g} / \mathrm{mL})$ in presence of $100 \mu \mathrm{g} / \mathrm{mL}$ of RNase for $30 \mathrm{~min}$ at $37^{\circ} \mathrm{C}$ in the dark. Data was acquired on a BD Accuri C6 flow cytometer (BD Immunocytometry Systems, San Jose, CA) and analyzed. Twenty thousand events were analyzed for each sample. Appropriate gating was used to select standardized cell population.

\section{Estimation of reactive oxygen species (ROS) production}

Hydrogen peroxide, hydroxyl radicals and peroxy radicals were detected via carboxy-H2DCFDA using flow cytometry. Cells $\left(1 \times 10^{6}\right)$ were seeded in a $100 \mathrm{~mm}^{2}$ culture dishes and treated with $50 \mu \mathrm{M}$ or $100 \mu \mathrm{M}$ BT for 6 and 24 hrs. After treatment, the cells were washed with PBS $(1 \times)$, collected by centrifugation after trypsinization, re-suspended in fresh PBS and incubated with $5 \mu \mathrm{M}$ 5,6-carboxy-2',7'-dichlorodihydrofluorescein diacetate (carboxy- $\mathrm{H}_{2} \mathrm{DCFDA}, \mathrm{C} 400$, Invitrogen, Eugene, Oregon, USA) for $30 \mathrm{~min}$ at $37^{\circ} \mathrm{C}$. The cells were washed twice with DPBS, re-suspended in an equal volume of DPBS and fluorescence measured with flow cytometry. Data was acquired on a BD Accuri C6 flow cytometer and analyzed using Accuri C6 software (BD ImmunocytometrySystems, San Jose, CA). Twenty thousand cells were analyzed for each sample. Subsequent cell viability assay with ascorbic acid pretreatment were performed (see cell viability assay above).

\section{Western blot analysis}

Western blotting was carried out to analyze expression of effector caspase 3 and caspase 7, using specific antibodies. Cellular pro-survival markers (pAkt, pNF-кB p65), pro-apoptotic signaling markers (pP38 MAPK) and important cell cycle regulatory proteins such as p27Kip1 and $\mathrm{p} 21^{\mathrm{Cip} 1}$ were also analyzed by western blotting. Additionally, NF-kB regulated genes involved in cell survival, e.g., IkB $\alpha$, xIAP, bcl-2, bcl-xl and were analyzed by western blotting.

Cells were seeded into $100 \mathrm{~mm}^{2}$ tissue culture dishes $\left(5 \times 10^{5}\right.$ cells/dish $)$ and treated with $50 \mu \mathrm{M}$ or $100 \mu \mathrm{M}$ BT. Following 24 hrs of treatment, cells were harvested by trypsinization, washed with PBS and suspended in cell extraction buffer (Invitrogen, Carlsbad, CA) containing $10 \mathrm{mM}$ Tris, $\mathrm{pH} 7.4,100 \mathrm{mM} \mathrm{NaCl}, 1 \mathrm{mM}$ EDTA, $1 \mathrm{mM}$ EGTA, $1 \mathrm{mM} \mathrm{NaF}, 20 \mathrm{mM}$ Na4P2O7, $2 \mathrm{mM}$ Na3VO4, 1\% Triton X-100, 10\% glycerol, 0.1\% SDS, $0.5 \%$ deoxycholate protease inhibitor cocktail and PMSF. Following heat denaturation, Lammli sample buffer along with $\beta$-mercaptoethanol was added to lysates and subjected to SDS-PAGE electrophoresis and immunoblotting. Following incubation with respective primary antibodies for overnight at $4^{\circ} \mathrm{C}$, and appropriate secondary antibodies (Licor), the proteins on the blots were detected by Licor image analyzer.

\section{Autotaxin (ATX) assay}

The phosphodiesterase activity of ATX was measured using a modification of the method of Razzell and Khorana [16]. ATX is secreted into media. After treatment with BT, cell-free supernatants were collected for ATX estimation. The cells were gently scraped off for analysis of cellular protein levels, according to the method of Lowry et al., [17]. The concentration of ATX was normalized with respect to the cell mass of samples in each well. To estimate ATX, cell free culture media $(100 \mu \mathrm{L})$ was incubated with $100 \mu \mathrm{L}$ substrate containing $p$-nitrophenylphosphonate ( $\mathrm{pNppp}$ ) at a final concentration of $5 \mathrm{mM}$ prepared in $50 \mathrm{mM}$ Tris- $\mathrm{HCl}$ buffer, 
$\mathrm{pH}$ 9.0. After $30 \mathrm{~min}$ incubation at $37^{\circ} \mathrm{C}$, the reaction was stopped by the addition of $100 \mu \mathrm{L}$ of $0.1 \mathrm{M} \mathrm{NaOH}$ solution. The reaction product was measured by reading the absorbance at $410 \mathrm{~nm}$. The percent of ATX inhibition of treated cells was calculated against untreated cells.

\section{Statistical analysis}

All data were expressed as mean \pm SD. Comparisons between untreated and each treated group were performed by Student's t-test. The significance level was set at $\mathrm{p}<0.05$.

\section{Results}

Cytotoxic effects of BT on ovarian cancer cell lines

As shown in Figure 1, treatment with increasing concentrations of BT resulted in dose dependent reduction in cell viability in all the cell lines tested. At $72 \mathrm{hrs}$ post treatment, the sensitivities to BT can be ranked from high to low as A2780 $\left(\mathrm{IC}_{50}-19 \mu \mathrm{M}\right)>\mathrm{A} 2780-\mathrm{CDDP}$ $\left(\mathrm{IC}_{50}-24 \mu \mathrm{M}\right)>$ SKOV-3 $\left(\mathrm{IC}_{50}-36 \mu \mathrm{M}\right)>$ OVACAR-3 $\left(\mathrm{IC}_{50}-44 \mu \mathrm{M}\right)>\mathrm{IGROV}-1\left(\mathrm{IC}_{50}-55 \mu \mathrm{M}\right)>$ IGROV1CDDP $(59 \mu \mathrm{M})$ (Table 1). Interestingly, cisplatin-resistant
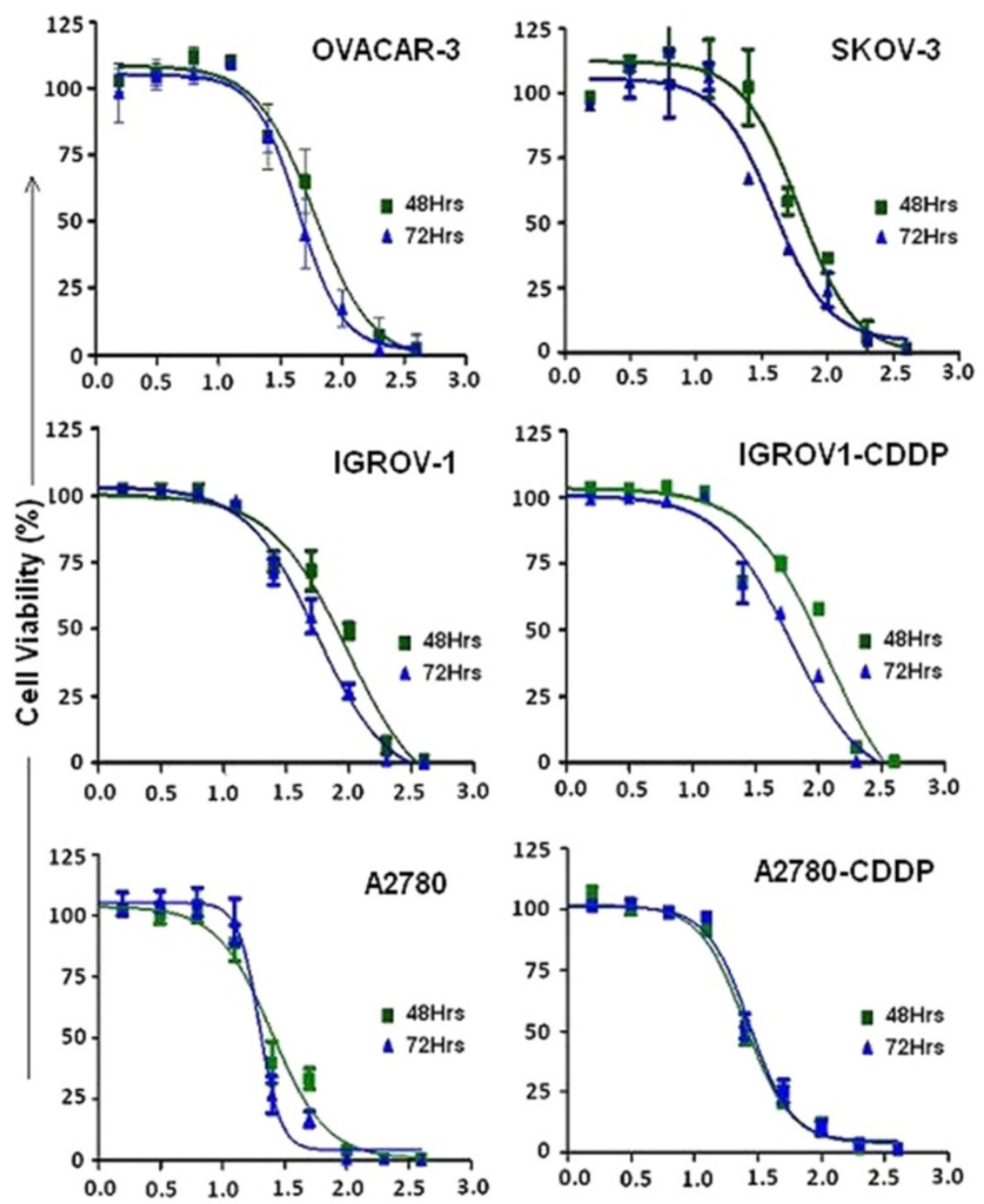

Log BT Conc. [uM]

Figure 1 Bithionol dose response curves. Cytotoxic effects of BT on a panel of ovarian cancer cell lines with varying cisplatin sensitivities. Cells were treated with different concentrations of BT for 48 or 72 hrs. Cell viability was determined by PrestoBlue Cell Viability Reagent as described in Materials and Methods. Control cells (vehicle treated) were considered as 100\% viable against which treated cells were compared. Experiments were performed in triplicate. Data was expressed as mean \pm SD of triplicate experiments. Dose response curves to calculate $I_{50}$ values were plotted using Graph Pad Prism Software. 
Table 1 IC $_{50}$ values for Bithionol in various ovarian cancer cell lines

\begin{tabular}{llcc}
\hline & & $\mathbf{4 8} \mathbf{~ h r s}$ & $\mathbf{7 2} \mathbf{~ h r s}$ \\
\hline 1 & OVACAR-3 & $59 \pm 9$ & $44 \pm 7$ \\
2 & SKOV-3 & $60 \pm 2$ & $36 \pm 7$ \\
3 & IGROV-1 & $98 \pm 14$ & $55 \pm 12$ \\
4 & IGROV-1 CDDP & $117 \pm 21$ & $59 \pm 8$ \\
5 & A2780 & $26 \pm 4$ & $19 \pm 3$ \\
6 & A2780-CDDP & $27 \pm 3$ & $24 \pm 3$ \\
\hline IC 50 & &
\end{tabular}

variants of A2780 and IGROV-1 showed near similar BT $\mathrm{IC}_{50}$ values to their cisplatin-sensitive variants, although significant difference were observed with cisplatin $\mathrm{IC}_{50}$ values (Table 2).

\section{Assessment of type of cell death induced by bithionol Effect of BT on lactate dehydrogenase (LDH) activity (necrosis assessment)}

Our results demonstrate that LDH release is dependent on BT concentration and treatment time. As shown in Figure 2A (line graph), at 6 and 24 hrs post treatment, no significant LDH release was observed at lower concentrations $(12.5 \mu \mathrm{M}-100 \mu \mathrm{M})$, but only occurred at higher concentration $(200 \& 400 \mu \mathrm{M})$. However, at $48 \mathrm{hrs}$ post-treatment, LDH release was observed even at lower concentration (100 $\mu \mathrm{M} \mathrm{BT})$ especially in OVACAR-3 and A2780 cell lines. All cell lines tested exhibited a similar trend.

\section{Effect of BT on caspase 3/7 activity (apoptosis assessment)}

Our results demonstrate that BT induces caspase activity in all cell lines tested. Caspase activity was found to be dependent on time and concentration of BT. As shown in Figure 2A (column graph), at 6 hrs post treatment, caspase activity was observed only at $200 \mu \mathrm{M}$ in all cell lines except A2780 which showed significant activity even at $50 \mu \mathrm{M}$ BT. However, at 24 hrs post treatment, significant caspases activity was observed at lower concentrations $(50 \mu \mathrm{M}-100 \mu \mathrm{M}$ BT $)$. At 48 hrs post

Table 2 IC $_{50}$ values for Cisplatin in isogenic ovarian cancer cell line pairs

\begin{tabular}{|c|c|c|c|}
\hline & & $48 \mathrm{hrs}$ & $72 \mathrm{hrs}$ \\
\hline 1 & IGROV-1 & $13 \pm 1$ & $3 \pm 0.05$ \\
\hline 2 & IGROV-1 CDDP & $60 \pm 8$ & $18 \pm 1$ \\
\hline 3 & A2780 & $22 \pm 3$ & $10 \pm 2$ \\
\hline 4 & A2780-CDDP & $42 \pm 6$ & $23 \pm 4$ \\
\hline
\end{tabular}

$\mathrm{IC}_{50}$ values $(\mu \mathrm{M})$ for Cisplatin - Mean $\pm \mathrm{SD}$.

$\mathrm{IC}_{50}$ values for Cisplatin in isogenic ovarian cancer cell line pairs consisting of Cisplatin-sensitive parental lines and stable Cisplatin-resistant sub-lines derived by in vitro selection with Cisplatin. treatment, caspase activity was still observed at lower concentrations but absent at higher concentrations. No caspase activity was observed at $400 \mu \mathrm{M}$ BT at any time points.

Western blot analysis demonstrated significant expression of caspase 3 in all cell lines tested. Similarly, activation of caspase-7, as indicated by the appearance of a $20 \mathrm{kDa}$ band, was observed in all BT treated cell lines. As compared to all cell lines, IGROV-1CDDP exhibited weak caspase-7 expression (Figure 2B). Caspases expression peaked at $24 \mathrm{hrs}$ post treatment. The activation of proteolytic caspases following drug exposure resulted in the cleavage of $118 \mathrm{kDa}$ PARP-1 protein into an $89 \mathrm{kDa}$ fragment in all BT treated cell lines (Figure 2B). Untreated cells did not show any PARP cleavage. All cell lines exhibited similar results.

\section{Morphological hallmarks of apoptosis}

As shown in Figure 3, normal control cells stained very faintly with the Hoechst stain but treated cells had a stronger blue fluorescence indicative of apoptosis. Strong blue fluorescence indicates highly condensed chromatin, characteristic of apoptotic cells. These results are also confirmed by TUNEL assay which detects DNA fragmentation. As shown in Figure 3 (line graph), increased DNA fragmentation was observed with increasing BT concentrations in all the cell lines tested.

\section{Analysis of mitochondrial transmembrane potential}

BT treatment resulted in slight decrease in mitochondrial potential as early as $6 \mathrm{hrs}$ post treatment. At $24 \mathrm{hrs}$ post-treatment, significant mitochondrial loss was observed in all cell lines as indicated by shifts in peaks between untreated, $50 \mu \mathrm{M} \mathrm{BT}$ and $100 \mu \mathrm{M}$ BT treated cells (Figure 4). As compared to OVACAR-3 and IGROV-1 and IGROV1-CDDP, loss of mitochondrial potential was greater in SKOV-3, A2780 and A2780-CDDP at $24 \mathrm{hrs}$ post treatment.

\section{Mechanism(s) of BT induced cytotoxicity \\ Effect of BT on cell cycle in ovarian cancer cell lines}

At $24 \mathrm{hrs}$ post treatment, cell-cycle analysis of BT treated ovarian cancer cell lines revealed a significant increase in the G1-phase cell population with a concomitant decrease in $\mathrm{S}$ and $\mathrm{G} 2$ phases as compared to untreated control (Figure 5A and B). OVACAR-3 did not show significant change in G2 phase $(\mathrm{p}>0.05)$.

Western blot analysis of cell cycle regulatory proteins revealed up-regulation of both P27 (kip1) and p21 upon $\mathrm{BT}$ treatment (Figure $5 \mathrm{C}$ ).

\section{Effect of BT on ROS generation}

Cells treated with BT showed ROS generation as early as $6 \mathrm{hrs}$ post treatment. This was more remarkable when treatment was extended up to $24 \mathrm{hrs}$. As shown in 


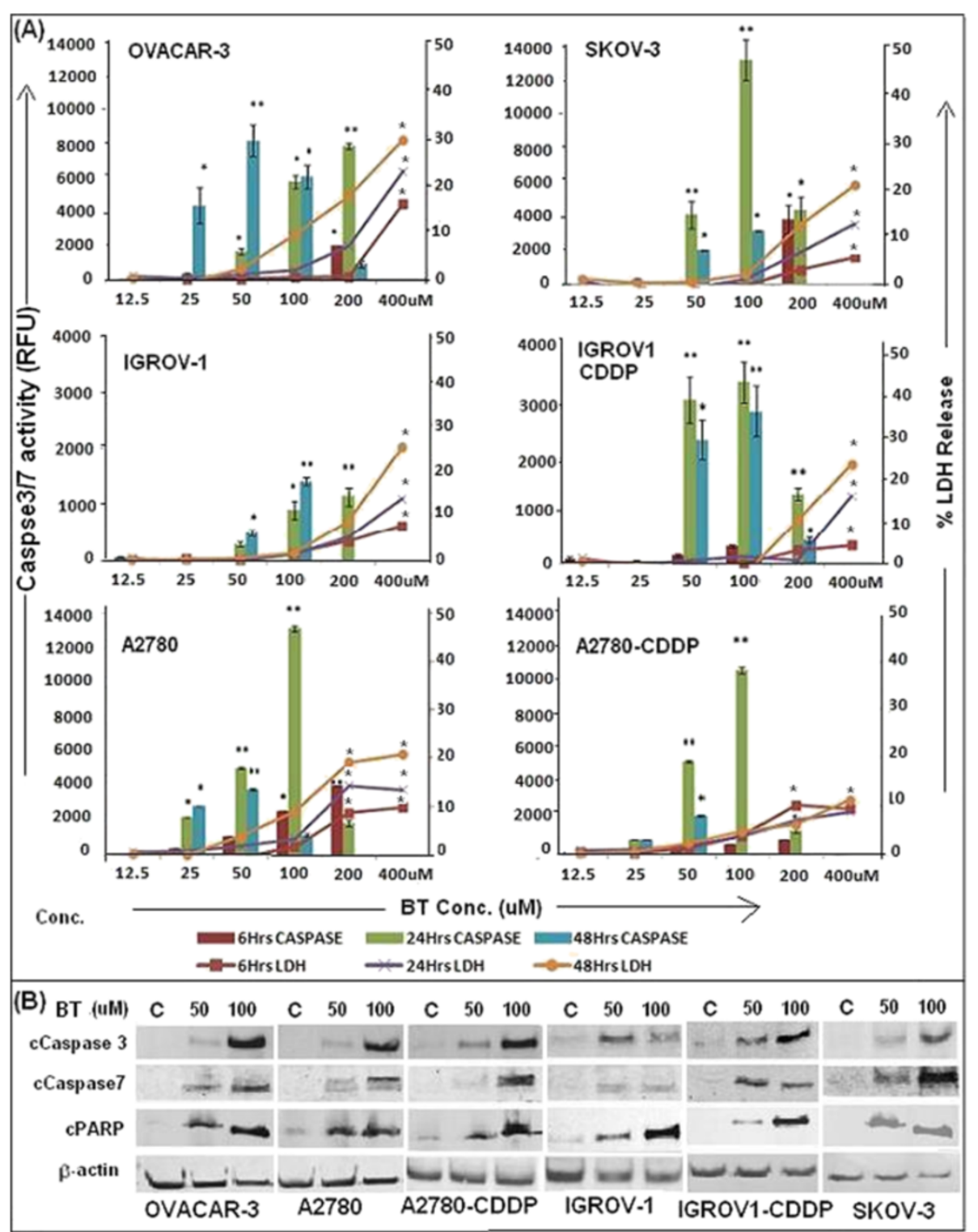

Figure 2 Assessment of type of cell death induced by BT on various ovarian cancer cell lines. (A) Effect of BT on casapses $3 / 7$ (columns) and LDH activities (line graph). Caspase 3/7 activity was measured using Caspase-Glo 3/7 Assay kit from Promega and LDH release was measured by using Cyto-Tox-One Homogenous Membrane Integrity kit (Promega). Cells were treated with BT for 6, 24 and 48 hrs. Vehicle treated (media with 1\% DMSO) were considered as control against which treated cells were compared. Experiments were performed in triplicate. Data was expressed as mean \pm SD of triplicate experiments. ${ }^{*} p<0.05$ and ${ }^{* *} p<0.01$, as compared to control, Students" test. (B) Activation of Caspases 3 and 7 and degradation of PARP as shown by western blot analysis. Ovarian cancer cell lines were treated with BT at $50 \mu \mathrm{M}$ or $100 \mu \mathrm{M}$ for 24 hrs. Analysis of the expression of proteins in the lysates of treated and untreated cells (control) was carried out by PAGE and western blot analysis as described (Materials and Methods). Primary antibodies against activated caspase-3, caspase-7 and cleaved PARP were used. As an internal standard for equal loading, blots were probed with an anti - $\beta$ - actin antibody.

Figure 6A, elevated ROS levels were observed in all cell lines as indicated by shift in peaks between untreated, $50 \mu \mathrm{M}$ BT and $100 \mu \mathrm{M}$ BT treated cells.

Follow up cell viability assays in the presence of antioxidant ascorbic acid, demonstrated at least a $20-30 \%$ restoration of cell viability in the presence of $1 \mathrm{mM}$ ascorbic acid in OVACAR-3, SKOV-3, IGROV-1 and A2780 cells. Interestingly, greater restoration of cell viability was observed in cisplatin-resistant variants of IGROV-1 and A2780. In IGROV-1CDDP, 47\% cell viability was restored and A2780-CDDP showed 40\% restoration (Figure 6B).

\section{Effect of BT on pro-survival (pAkt, NF-kB) and pro-apoptotic} (pP38) signalling molecules

As shown in Figure 7A, western blot analysis revealed significant activation of pro-apoptotic marker, p38, when 


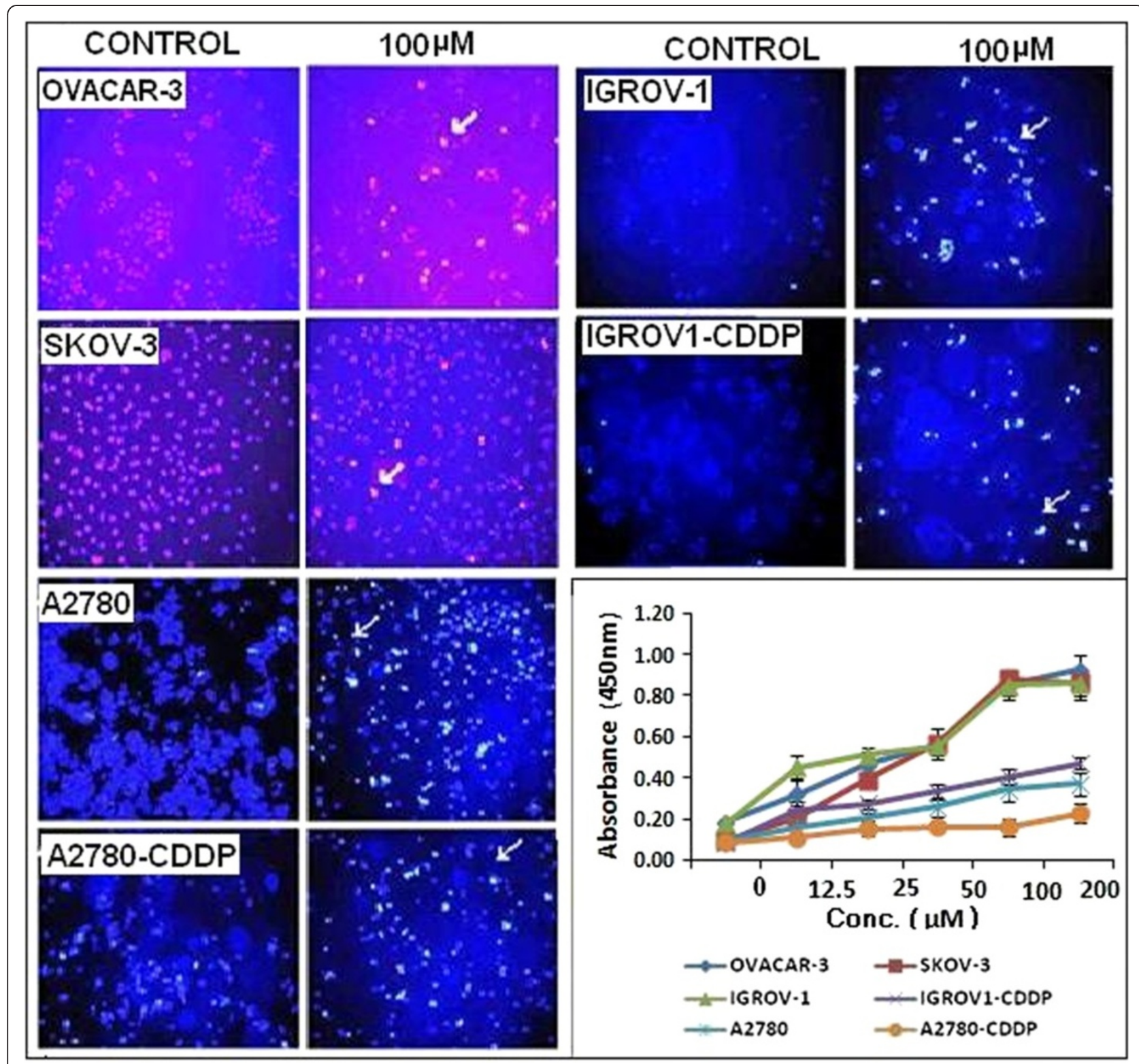

Figure 3 Hoechst staining of cell to detect BT induced apoptosis. Ovarian cancer cell lines were treated with $100 \mu$ M BT for 24 hrs. Treated/ untreated cells were stained with Hoechst 33258 and visualized by fluorescence microscopy. Representative images were taken with an inverted microscope (Olympus H4-100, CCD camera) and 20x objective. Graph: Quantification of percent of apoptosis in terms of DNA fragmentation using Trevigen's TACS 2 TdT in Situ Apoptosis Detection Kit (TUNEL assay). Cells were treated with BT as explained earlier. At the end of the treatment time, labelled nucleotides were added and detected with HRP - HRP substrate (TACS-Sapphire) system. The absorbance was measured at $450 \mathrm{~nm}$ using a microplate reader, Multiskan (Thermo Scientifics). Experiments were performed in duplicate. Data was expressed as mean \pm SD of duplicate experiments.

cells were treated with BT for 24 hrs. However, a cell viability assay using SB203580 pre-treatment (an inhibitor of p38) did not restore cell viability (Figure 7B).

Western blot analysis of pro-survival marker pAkt showed decreased expression at 24 hrs post-BT treatment in all cell lines except for OVACAR-3 and IGROV1 where increased expression was observed at $50 \mu \mathrm{M}$ but decreased at $100 \mu \mathrm{M}$ BT (Figure 7A). Additionally, a cell viability assay using LY294002 pre-treatment (an inhibitor of pAkt) neither enhanced BT cytotoxicity nor restored cell viability at $48 \mathrm{hrs}$ post BT treatment.

Pro-survival marker, phospho-NF-кB p65, showed decreased expression at $24 \mathrm{hrs}$ post-BT treatment in all cell lines at $100 \mu \mathrm{M}$ BT (Figure 7A). Interestingly, downregulation of several genes regulated by NF-kB (pIkB $\alpha$, XIAP, pbcl-2, bcl-xL) was observed in all cell lines (Figure 7C). Expression of pro-survival marker XIAP, a direct inhibitor of executioner caspases, such as 

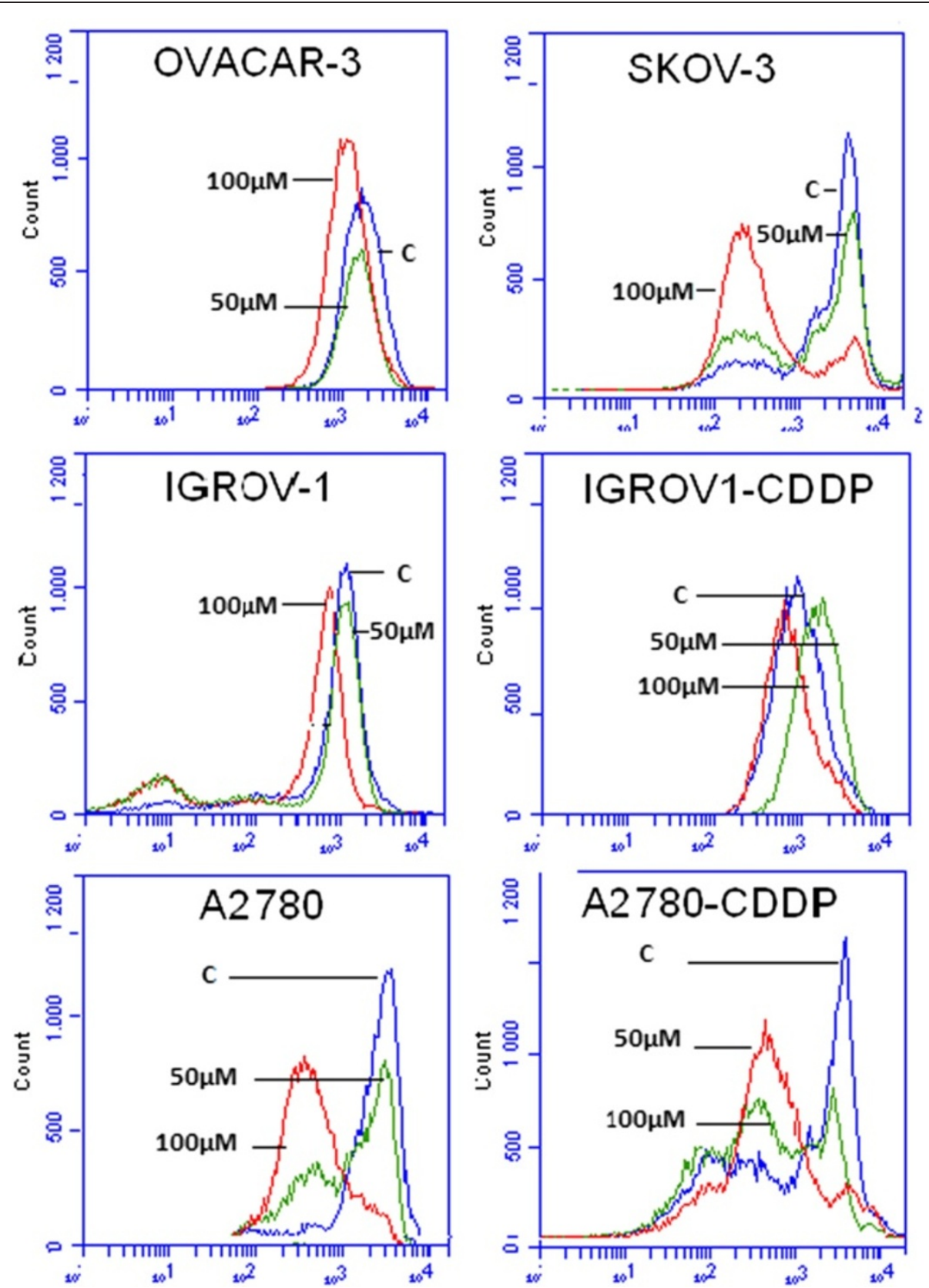

Figure 4 Detection of loss of mitochondrial trans-membrane depolarization potential upon BT treatment. Cell lines were treated with 100 MM BT for 24 hrs. Mitochondrial potential was determined by flow cytometry using Rhodamne-123. Data was acquired by BD's Accuri C6 flow cytometer system and analyzed. Data was presented as relative-fluorescence intensity in a 2-dimensional FACS profile (standardized gating, 20,000 events). Loss of transmembrane potential was shown by shift in peaks in treated cells as compared to control (C-vehicle treated). All experiments were performed in triplicate.

caspase-3, was down-regulated within 24 hrs following the BT treatment in all the cell lines (Figure 7C).

Activation of NF- $\kappa B$ occurs via phosphorylation of IкB $\alpha$ at Ser32 and Ser36. This is followed by proteasome-mediated degradation resulting in release and nuclear translocation of active NF-kB, where it regulates expression of several pro-survival or pro-apoptotic proteins, e.g., pIkB $\alpha$, pbcl-2, bcl-xL, xIAP. Expression of
pNFkB, pIkB $\alpha$, XIAP, pbcl-2 and bcl-xL were assessed by western blotting. pNFkB was detected using a specific antibody that detects NF- $\mathrm{kB}$ p65 only when phosphorylated at Ser536. Similarly, expression of phospholkB $\alpha$ was detected using a monoclonal antibody that detects endogenous levels of IkB $\alpha$ only when phosphorylated at Ser32. As described in Figure 7A, pro-survival marker, phospho-NF-kB p65, showed decreased expression at 


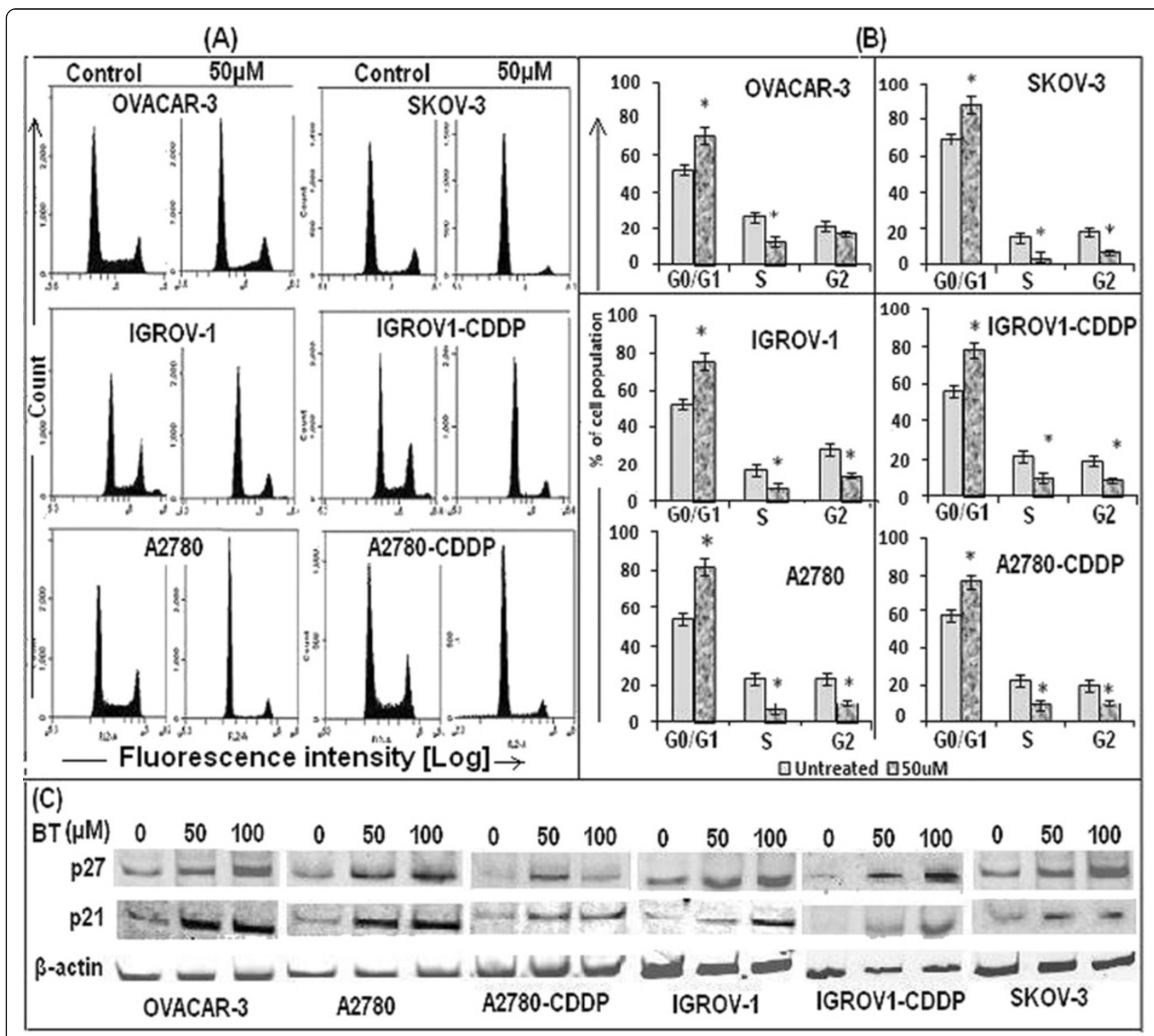

Figure 5 Effect of BT on cell cycle progression of ovarian cancer cell lines. (A) Cell cycle analysis was carried out by flow cytometry. Cells were treated with $50 \mu \mathrm{M}$ BT for $24 \mathrm{hrs}$. At the end of the incubation period, cells were collected, fixed and stained with $50 \mu \mathrm{g} / \mathrm{mL}$ of propidium iodide and $100 \mathrm{\mu g} / \mathrm{mL}$ of RNase for $30 \mathrm{~min}$ at $37^{\circ} \mathrm{C}$ in the dark. Data was acquired on a BD Accuri C6 flow cytometer and analyzed. Twenty thousand events were analyzed for each sample. Appropriate gating was used to select standardized cell population. (B) Graphical representation of cell cycles analysis by FACS. Data was expressed as mean \pm SD of triplicate experiments. ${ }^{*} p<0.05$, as compared to untreated control, students $\mathrm{t}$ test. (C) Expression of cyclin-dependent kinase inhibitors such as $\mathrm{p} 27^{\mathrm{kip} 1}$ and $\mathrm{p} 21^{\mathrm{Cip} 1}$ in BT treated cell lines, as analyzed by western blotting of cellular lysates using appropriate primary and secondary antibodies. Ovarian cancer cell lines were treated with BT at $50 \mu \mathrm{M}$ or $100 \mu \mathrm{M}$ for 24 hrs.

24 hrs post BT treatment in all cell lines at $100 \mu \mathrm{M}$ BT. Similarly, pIkB $\alpha$ levels were reduced at 24 hrs posttreatment. The extent of decrease varied between cell lines with a significant decrease observed in A2780, SKOV-3 and OVACAR-3. Compared to all cell lines, A2780-CDDP showed weak expression of $\mathrm{pIkB} \alpha$ at all concentrations. Interestingly, down-regulation of several genes regulated by NF-kB (pIkB $\alpha$, XIAP, pbcl-2, bcl-xL) was observed in all cell lines (Figure 7C). BT at $100 \mu \mathrm{M}$ consistently inhibited pbcl-2 and bcl-xL in all cell lines.
Phospho-Bcl-2 was detected using an antibody that detects Bcl-2 only when phosphorylated at threonine56. Expression of pro-survival marker XIAP, a direct inhibitor of executioner caspases, such as caspase-3, was down-regulated within $24 \mathrm{hrs}$ following the BT treatment $(100 \mu \mathrm{M})$ in all the cell lines (Figure $7 \mathrm{C}$ ).

\section{Effect of BT on autotaxin inhibition}

BT treatment significantly inhibited ATX in all the cell lines tested (Figure 8). BT induced ATX inhibition was 


\section{(A)}

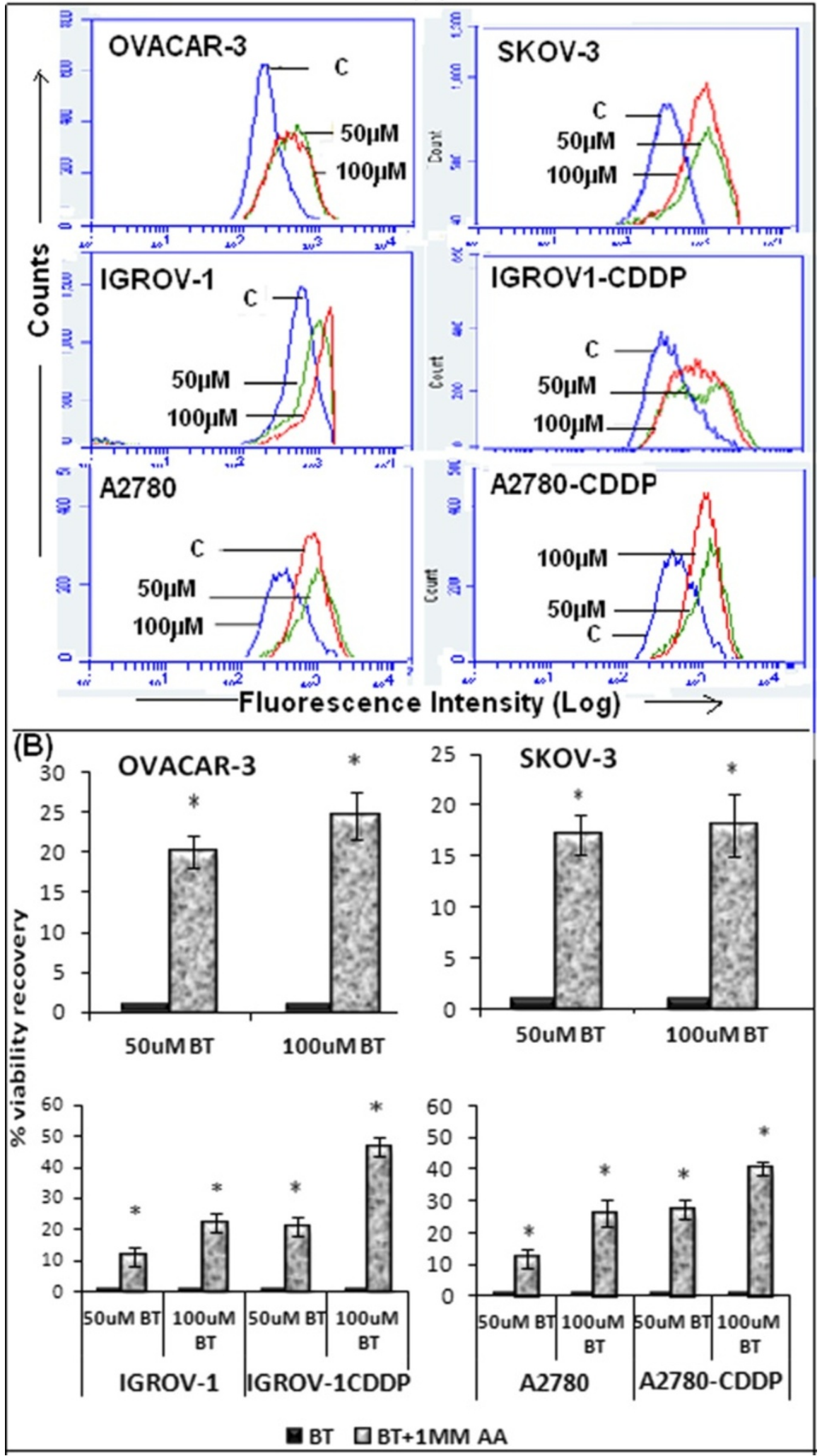

Figure 6 (See legend on next page.) 
(See figure on previous page.)

Figure 6 Detection of intracellular ROS following BT treatment in ovarian cancer cell lines. (A) Detection of ROS by flow cytometry. Cells $\left(1 \times 10^{6}\right)$ were treated with $50 \mu \mathrm{M}$ or $100 \mu \mathrm{M}$ BT for $24 \mathrm{hrs}$. After treatment, cells were collected, washed and incubated with $5 \mu \mathrm{M}$ C400 and analyzed by flow cytometry. Data was presented as relative-fluorescence intensity in a 2-dimensional FACS profile (standardized gating, 20,000 events). Enhanced ROS generation was shown by shift in peaks in treated cells as compared to control (labeled as ' $\mathbf{C}^{\prime}$ ). All experiments were performed in triplicate. (B) Effect of antioxidant ascorbic acid on BT treated cells. Cells were pre-treated with $1 \mathrm{mM}$ ascorbic acid for 2 hrs before addition of drug and further incubated for 48 hrs with both BT and ascorbic acid. Cell viability was determined by PrestoBlue reagent. Control (untreated) cells were considered as 100\% viable against which treated cells were compared. The results represent \% viability recovery when compared with $100 \mu \mathrm{M}$ BT treated cells. Experiments were performed in triplicate. Data was expressed as mean \pm SD of triplicate experiments. ${ }^{*} p<0.05$ and ${ }^{* *} p<0.01$, as compared to control, Students't test.

time dependent as more inhibition was observed at $48 \mathrm{hrs}$ post treatment than at $24 \mathrm{hrs}$. Approximately $40-60 \%$ inhibition was observed at $100 \mu \mathrm{M}$ BT at $48 \mathrm{hrs}$ post treatment in all cell lines tested. The extent of ATX inhibition was nearly similar in all cell lines.

\section{Discussion}

Drug resistance is a major cause for ovarian cancer recurrence. New drug discovery requires significant resources and time. Alternatively, the concept of 'drug repurposing' appears promising. In the present study, we explored the antitumor potential of $\mathrm{BT}$ in pre-clinical

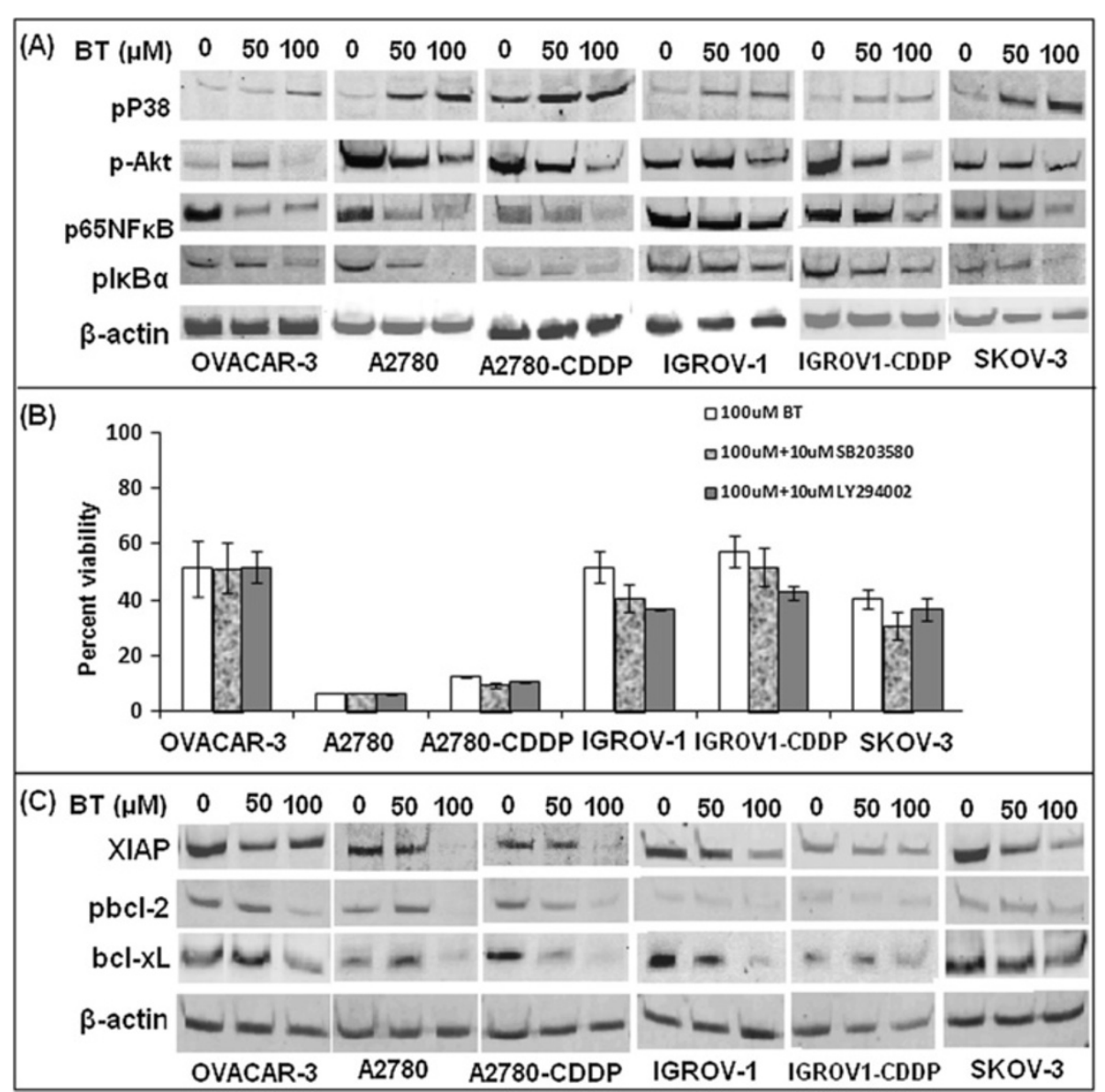

Figure 7 Effect of BT on pro-apoptotic (pP38) and pro-survival (pAkt, NF-kB) signalling molecules. (A) Cells were treated with $50 \mu \mathrm{M}$ or $100 \mu \mathrm{M}$ BT for 24 hrs, proteins extracted, subjected to electrophoresis and detected by western blotting using primary antibodies specifically recognizing the phosphorylated active forms of these proteins. As an internal standard for equal loading, blots were probed with an anti $\beta$-actin antibody. (B) Effect of p38 inhibitor SB203580 and pAkt inhibitor LY294002 on BT treated cells. To assess role of p38 and pAkt activation in BT induced cytotoxicity, cells were treated with $100 \mu \mathrm{M}$ BT in presence of $10 \mu \mathrm{M}$ of SB203580 or $10 \mu \mathrm{M}$ LY294002 (non-toxic conc.'s) for 48 hrs and cell viability determined by presto blue cell viability reagent. The results represent $\%$ viability when compared with untreated cells. Data was expressed as mean \pm SD of triplicate experiments. C. Effect of BT treatment on NF-kB regulated cell survival genes such as plkBa, xIAP, pbcl-2, bcl-xL, as analyzed by western blotting of cellular lysates. 


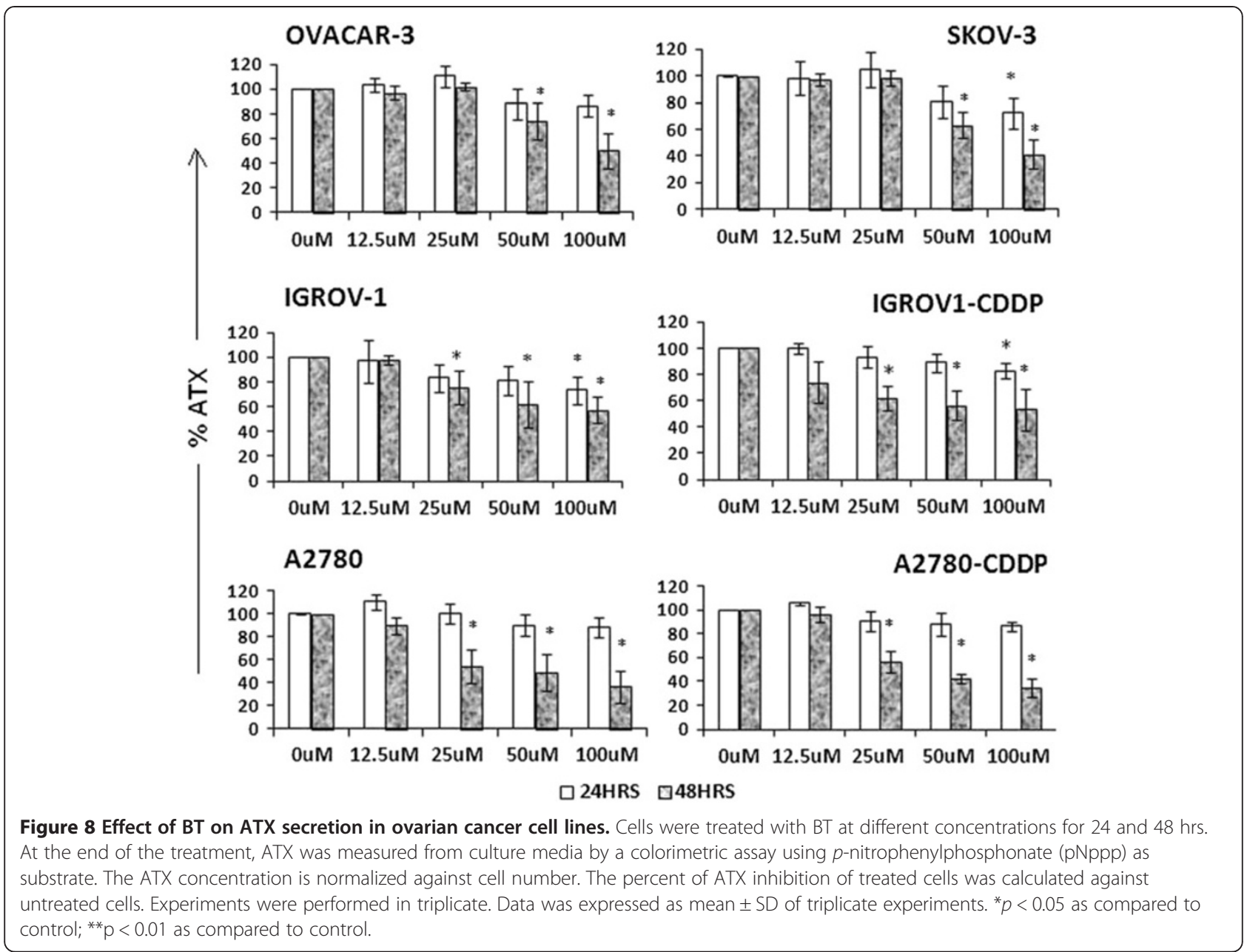

ovarian cancer model. BT was tested against a panel of ovarian cancer lines exhibiting varying sensitivities to cisplatin. Our results demonstrate the cytotoxic effects of BT towards all the ovarian cancer cells lines tested with $\mathrm{IC}_{50}$ values ranging from $19 \mu \mathrm{M}$ to $60 \mu \mathrm{M}$, at

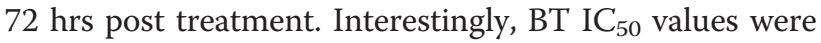
almost indistinguishable between cisplatin-sensitive and cisplatin-resistant variants of isogenic ovarian cancer cell line pairs, although cisplatin $\mathrm{IC}_{50}$ values varied significantly. These results are significant when considering that clinically, all recurrent ovarian cancers will eventually be platinum-resistant. Interestingly, $\mathrm{BT} \mathrm{IC}_{50}$ values observed for various ovarian cancer cell lines are significantly below the clinically tolerable doses of BT for humans. In several published studies, chronic BT dosing up to $50 \mathrm{mg} / \mathrm{kg}$ every other day was well tolerated with the $40 \mathrm{mg} / \mathrm{kg}$ dose level best tolerated. Fifty $\mathrm{mg} / \mathrm{kg}$ in three divided alternate daily doses for 5 days will maintain serum levels of BT in the range of 140 to $550 \mu \mathrm{M}$ in rabbits, dogs and humans $[13,18]$. Based on the fact that BT exerts similar cytotoxic effects on cisplatin-sensitive and resistant ovarian cancer cell lines with clinically tolerable $\mathrm{IC}_{50}$ values, it is reasonable to speculate that BT may be useful in halting ovarian cancer cell growth irrespective of the sensitivity that cells may display to cisplatin, and this merits further exploration.

It is well known that invalid apoptosis pathway has often been one of the hallmarks of cancer cells and an important cause of resistance to cytotoxic agents [19]. It is therefore essential to focus on type of cell death induced by therapeutic agents. Ability to induce apoptosis is a critical factor for effective treatment against cancer [20]. Previous reports show the inhibitory effect of BT on cervical cancer cell growth via induction of caspase 3/7 activity [14]. Our results also indicate that ovarian cancer cells undergo apoptosis upon BT treatment initially at lower concentrations. Hallmarks of apoptosis, such as nuclear condensation, DNA fragmentation, and loss of mitochondrial potential, were observed further demonstrating that BT triggers apoptosis in ovarian cancer cells. However, at higher concentrations, no caspase activity was detected while LDH was detected, indicating that cells die via necrosis at higher concentrations. The ability of BT to induce cell death via apoptosis makes this drug a good candidate for the treatment of ovarian cancer. 
This study also demonstrates that BT induces apoptosis in ovarian cancer cells via activation of proteolytic effector caspases such as Caspase 3 and 7 and subsequent cleavage/inactivation of PARP-1 (involved in DNA repair). Apoptosis is known to be mediated by two pathways, the extrinsic (death receptor) and the intrinsic (mitochondrial). The majority of anticancer (cytotoxic) drugs induce apoptosis via the intrinsic (mitochondrial cytochrome c/Apaf-1/caspase-9 pathway) [21,22]. Mitochondria are considered to be both a source and a target of ROS. Although we did not focus on which apoptotic pathway was induced by BT, decreased mitochondrial transmembrane potential following BT treatment implicates the intrinsic (mitochondrial) pathway. Disruption of mitochondrial potential can lead to oxidation of mitochondrial pores by ROS, resulting in release of cytochrome C into the cytosol [23]. Cytochrome C, Apaf1 (apoptotic protease activating factor-1) and dATP then form an apoptosome to which procaspase- 9 is recruited and activated. Caspase- 9 in turn activates downstream effector caspases -3 and -7 which execute the final steps of apoptosis.

We observed a switch from apoptosis to necrosis with increasing BT concentrations. Apoptosis is a carefully regulated, energy-dependent process that involves a complex cascade of events resulting in cell death. It is dependent on availability of ATP, which in turn depends on the correct function of mitochondria. As mentioned in our manuscript, BT causes mitochondrial transmembrane depolarization, thus affecting mitochondrial function. This disruption may cause ATP depletion to a level that is insufficient for cell survival, thus switching from apoptosis to necrosis. Additionally, reactive oxygen species (ROS) are known to cause apoptosis or necrosis, depending on the amount and type of ROS generated [24]. We postulate that high concentrations of BT lead to increased ROS, ultimately causing severe cellular injury. High levels of ROS can inhibit apoptosis by inactivating caspases by oxidation of their thiol groups. Furthermore, ROS can affect mitochondrial energy (ATP) production causing depletion of ATP. These events would ultimately switch cells to necrosis.

Inhibition of the cell cycle is a known target for the treatment of cancer [25-28]. Anticancer agent may cause cell cycle arrest via altering the regulation of cell cycle machinery. Various regulatory proteins, including cyclin E, cyclin D1, cyclin D2, cyclin A, CDK2, CDK4 and the CDK inhibitors $\mathrm{p} 27^{\mathrm{Kip} 1}$ and $\mathrm{p} 21^{\mathrm{Cip} 1}$ are known to regulate cell cycle. It is well known that kinase activities of CDK-cyclin complexes are essential for progression of cell cycle at many check points [29-31]. p21 $1^{\text {Cip }}$ is regarded as universal inhibitor of cyclin-CDK complexes [29-31], thus blocking the entry of cells at the $\mathrm{G}_{1}-\mathrm{S}$ phase transition checkpoint and induce apoptosis [32].
Our data demonstrate that BT treatment resulted in G1phase cycle arrest and up-regulation of the expression of $\mathrm{p} 27^{\mathrm{Kip} 1}$ and $\mathrm{p} 21^{\mathrm{Cip} 1 .}$ Increased expression of CDK inhibitors $\mathrm{p} 21^{\mathrm{cip} 1}$ and $\mathrm{p} 27^{\mathrm{kip} 1}$ may result in increased association with CDKs, thus inhibiting their activity. The cascade of downstream events in response to BT treatment may lead to blockage of the cell cycle at the G1to-S phase transition, and thus halting ovarian cancer cell growth. Additionally, cell cycle arrest following BT treatment could be ROS mediated. We showed that BT enhanced ROS generation. ROS mediated inactivation of CDKs by via oxidation [33] and enhanced expression of p21 can cause cell cycle arrest in G1- and S-phases resulting in reduced cellular proliferation. ROS mediated DNA damage is known to cause stabilization and elevation of known tumor suppressor protein, p53, which in turn induces and enhances the synthesis of p21 [33]. As mentioned earlier, p21 is known inhibitor of CDK activity. These observations suggest that cell cycle regulation is one of the mechanisms of action of BT in ovarian cancer cells.

Increased ROS generation can be frequently observed in cells subjected to anticancer drugs such as paclitaxel, cisplatin, doxorubicin [34,35]. Accumulation of ROS inside the cell may result in apoptosis or terminal differentiation [36]. Our results demonstrate significant generation of ROS in BT treated cells as compared to untreated cells in both a concentration and time dependent fashion. In order to ascertain role of ROS in BT induced cytotoxicity, we performed a cell viability assay in the presence of BT and antioxidant, ascorbic acid. Our results demonstrate a significant restoration of cell viability in the presence of $1 \mathrm{mM}$ ascorbic acid in all cell lines tested. Interestingly, cisplatin-resistant variants of IGROV-1 and A2780 demonstrated greater responses to ascorbic acid pre-treatment than their cisplatinsensitive counterparts. These observations imply a significant role of ROS in BT mediated cytotoxicity, and more so in cisplatin-resistant cell lines. This unique effect of BT on ROS generation in cisplatin-resistant cells implies that BT could have a role in the treatment of platinum-resistant ovarian cancer, either alone or in combination with other cytotoxic drugs.

Reactive oxygen species are known to modify signalling molecules important in cellular survival such as Akt1, and transcription factors including NF-kB, due to the presence of redox-sensitive cysteine or methionine groups that are susceptible to oxidation [37]. It is widely reported that cisplatin-resistant cell lines maintain high levels of Akt and NF-kB as compared to cisplatinsensitive cell lines [38]. Keeping in mind the greater role of ROS generation observed in cisplatin resistant variants upon BT treatment, it may be possible that modification of pro-survival molecules such as Akt and NF-kB 
via oxidation may be a possible mechanism of action of BT, especially in cisplatin-resistant cell lines.

To further define key signalling responses of ovarian cancer cells to treatment with BT, we analyzed the expression and activation/phosphorylation of cellular markers involved in pro-apoptotic (p38) or pro-survival (pAkt, NF-kB) signalling. Immunoblotting of PAGEseparated cellular lysates revealed sustained activation of pP38 MAPK upon BT treatment. In order to assess the role of pP38 signalling in BT induced cytotoxicity, a cell viability assay was performed in the presence of a p38 inhibitor, SB203580. Pre-treatment with the p38 inhibitor did not restore cell viability when cells were treated with BT. These results rule out any significant role for p38 MAPK signalling in BT mediated cytotoxicity.

Activation of the PI-3 K/Akt pathway has been shown to induce resistance to apoptosis induced by a number of drugs and has been linked to cisplatin resistance in ovarian cancer cell lines $[39,40]$. In view of this, we studied the expression of pAkt upon BT treatment. Significant down-regulation of pAkt expression was observed at $24 \mathrm{hrs}$ post BT treatment. It has been reported that Akt inactivation is essential for drug sensitivity [41,42]. In order to understand whether further inactivation of Akt can enhance the effectiveness of BT, we performed cell viability assays in the presence of PI3k inhibitor LY294002. LY294002 neither enhanced BT cytotoxicity nor restored the cell viability at 48 hrs post BT treatment. These results show that the Akt pathway may not mediate BT cytotoxicity in ovarian cancer cell lines.

Inhibition of the IKK/NF- $\kappa \mathrm{B}$ activation pathway is considered an effective target for many anticancer drugs [43]. NF-kB inhibition in cancer cells has been shown to enhance chemotherapeutic response $[44,45]$. BT has also been reported to inhibit NF-kB signalling via inhibition of $\mathrm{IkB} \alpha$ phosphorylation in vitro [14]. Given the relevance of the NF- $\mathrm{KB}$ pathway in cancer, we assessed the effect of BT on phospho-NF- $k B$ p 65 and subsequent effect on NF-kB regulated proteins such as $\mathrm{pIkB} \alpha$, pbcl-2, bcl-xL, xIAP. Immunoblot analyses of whole cell lysate reveal decreased phospho-NF-kB p65 expression with increasing treatment time. BT treatment also downregulated the expression of $\mathrm{pIkB \alpha}$. Suppression of proliferation, induction of apoptosis and G1/S cell cycle arrest can all be due to inhibition of phosphorylation of NF-kB and IkB $\alpha$. BT can affect the DNA binding activity of NF$\mathrm{kB}$ directly via oxidation by ROS [46] and/or indirectly by inhibiting phosphorylation of NF-kB [47] and IkB $\alpha$. Phosphorylation of p65 at ser536 is essential for the DNA binding activity of NF- $\mathrm{kB}$ and it is known to be mediated via the PI3-kinase pathway [48]. Because BT also decreased pAkt expression, BT appears to indirectly reduce the DNA binding activity of NF- $\mathrm{kB}$ and affect the expression of NF- $\mathrm{KB}$ regulated anti-apoptotic proteins such as pIkB $\alpha$, pbcl-2, bcl-xL, xIAP. Indeed, we observed that NF-kB regulated proteins XIAP, bcl-xl, pbcl2 were down regulated upon BT treatment. XIAP is known to prevent apoptosis through up-regulation of PI3k/Akt cell survival signalling pathway [49]. Down-regulation of XIAP induces apoptosis and increases cisplatin sensitivity [49]. Inhibition of Bcl-xl may increase sensitivity to drugs such as carboplatin [50]. Expression of Bcl-2 is important in protection from drug-induced apoptosis in ovarian cancer thereby contributing to chemo-resistance [51,52]. These reports implicate NF-kB as a desirable target for anticancer agents in ovarian cancer. Our results demonstrate inhibitory effect of BT on NF-kB regulated proteins in ovarian cancer cell lines. BT treatment may promote apoptotic role for NF- $\mathrm{kB}$ by repressing antiapoptotic gene expression. Our results indicate an important role for NF-kB in BT induced cytotoxicity. However, further studies are required to confirm role of NF-kB in the anti-tumor effects of BT in ovarian cancer cell lines.

Autotaxin (ATX) inhibition was considered major mechanism of action of BT. Previously BT was shown to inhibit solid tumor growth in several preclinical cancer models by targeting ATX $[12,13]$. ATX plays a major role in modulation of the cellular process through its enzymatic production of lysophosphatidic acid (LPA). ATX is known to increases the aggressiveness and invasiveness of transformed cells, and directly correlates with tumor stage and grade in several human malignancies, including ovarian cancer $[53,54]$. ATX was shown to delay carboplatin induced apoptosis in ovarian cancer cells [55]. ATX inhibition was a proposed mechanism of action of BT in a melanoma model via inhibition of cell migration and invasion [13]. Given the significance of ATX in ovarian cancer [55-58], we studied the effect of BT on ATX in a panel of ovarian cancer cell lines. Our results clearly demonstrate significant inhibition of ATX in a concentration and time dependent fashion. ATX/ LPA stimulate the PI3-K, Akt, and ERK pathways and cause the activation of Rho and Rac [59]. These pathways facilitate cell division, survival, and migration [60,61]. BT may inhibit cell survival directly via inhibition of ATX or indirectly via inhibition of PI3-K, Akt or NF-kB pathways. Additionally, ATX is known to act as antioxidant, thus, protecting cells from oxidative stress [62]. The fact that BT treatment reduced ATX activity would imply that treated cells are exposed to a higher oxidative stress, eventually leading to apoptosis or necrosis. In view of the significance of ATX in chemoresistance in a majority of widely used chemotherapeutic agents, ATX inhibition or the LPA pathway can be considered as a significant therapeutic target. In our studies, we also observed a significant inhibition of ATX by BT.

Based on our findings, BT affects cells by causing mitochondrial dysfunction, ROS generation, cell cycle 
arrest and ATX inhibition, ultimately leading to cell death (apoptosis at low concentrations and necrosis at higher concentrations). BT appears to be a viable therapeutic agent against ovarian cancer cell lines in vitro. Further exploration of its anti-tumor potential in ovarian cancer animal xenograft model is essential before proceeding to clinical trials. Additionally, it is interesting to focus on synergistic, additive or antagonistic effects of BT in combination with other standard chemo drugs. These studies are currently underway.

\section{Conclusions}

We demonstrated the ability of BT to exert cytotoxic effects on a panel of ovarian cancer cell lines regardless of their cisplatin sensitivities. BT $\mathrm{IC}_{50}$ values observed in various ovarian cancer cell lines are well below the clinically tolerable doses of BT for humans. BT was shown to induce cell death via apoptosis. The mechanism(s) of actions appears to be via cell cycle regulation, ROS generation, NF-kB inhibition and ATX inhibition. ROS generation appears to be major mechanism of BT cytotoxicity in cisplatin-resistant variants. Agents causing cell cycle mediated apoptosis; NF-kB and ATX inhibition are already considered ideal candidates for the treatment of ovarian cancer. Because BT was shown to exhibit these desirable properties in in vitro, it is being further explored as an effective therapeutic agent in mice ovarian cancer xenograft model, either alone or in combination. In summary, the present study provides preclinical data supporting the possible therapeutic role of BT in the treatment of recurrent platinum-resistant ovarian cancers.

\section{Abbreviations \\ BT: Bithionol; ATX: Autotaxin; $\mathrm{IC}_{50}$ : Half maximal inhibitory concentration; ROS: Reactive oxygen species; NF-kB: Nuclear factor kappa B; MAPK: Mitogen-activated protein kinase; XIAP: $x$ linked inhibitor of apoptosis.}

\section{Competing interests}

The authors declare that they have no competing interests.

\section{Authors' contributions}

VA performed experimental procedures; LB and VA are responsible for study design, interpretation of results and writing of manuscript. Both authors read and approved the final manuscript

\section{Acknowledgements}

This work was supported by a NIH/NCI LRP grant NIH2674-4/OHGB1623 LRP to LB. We would also like to thank Krishna Rao, MD, PhD for his critical review of this manuscript.

Received: 1 October 2013 Accepted: 3 February 2014

Published: 4 February 2014

\section{References}

1. American Cancer Society: Cancer facts and figures 2013. Atlanta, Ga. American Cancer Society 2013:18.

2. Jemal A, Siegel R, Xu J, Ward E: Cancer statistics, 2010. CA Cancer J Clin 2010, 60(5):277-300.

3. Herzog TJ: The current treatment of recurrent ovarian cancer. Curr Oncol Rep 2006, 8(6):448-454
4. Agarwal R, Kaye SB: Ovarian cancer: strategies for overcoming resistance to chemotherapy. Nat Rev Cancer 2003, 3(7):502-516.

5. McGuire WP, Hoskins WJ, Brady MF, Kucera PR, Partridge EE, Look KY, Clarke-Pearson DL, Davidson M: Cyclophosphamide and cisplatin compared with paclitaxel and cisplatin in patients with stage III and stage IV ovarian cancer. N Engl J Med 1996, 34:1-6.

6. Piccart MJ, Bertelsen K, James K, Cassidy J, Mangioni C, Simonsen E, et al: Randomized intergroup trial of cisplatin-paclitaxel versus cisplatincyclophosphamide in women with advanced epithelial EOC: three-year results. J Nat/ Cancer Inst 2000, 92:699-708.

7. Kikuchi $Y$ : The mechanism of cisplatin-resistance in ovarian cancer. Hum Cell 2001, 14(2):115-133.

8. Leitao MM Jr, Hummer A, Dizon DS, Aghajanian C, Hensley M, Sabbatini P, Venkatraman E, Spriggs DR: Platinum retreatment of platinum-resistant ovarian cancer after nonplatinum therapy. Gynecol Oncol 2003, 91:123-129.

9. Lamberth E, Gregory WM, Nelstrop AE, Rustin GJ: Long-term survival in 463 women treated with platinum analogs for advanced epithelial carcinoma of the ovary: life expectancy compared to women of an age-matched normal population. Int J Gynecol Cancer 2004, 14:772-778.

10. Ott I, Gust R: Non platinum metal complexes as anti-cancer drugs. Arch Pharm 2007, 340:117-126.

11. Bacq Y, Besnier JM, Duong TH, Pavie G, Metman EH, Choutet P: Successful treatment of acute fascioliasis with bithionol. Hepatology 1991, 14:1066-1069

12. Braddock D: Autotaxin and lipid signaling pathways as anticancer targets. Curr Opin Investig Drugs 2010, 11:629-637.

13. Saunders LP, Ouellette A, Bandle R, Chang WC, Zhou H, Misra RN, De La Cruz EM, Braddock DT: Identification of small-molecule inhibitors of autotaxin that inhibit melanoma cell migration and invasion. Mol Cancer Ther 2008, 7(10):3352-3362.

14. Miller SC, Huang R, Sakamuru S, Shukla SJ, Attene-Ramos MS, Shinn P, Van Leer D, Leister W, Austin CP, Xia M: Identification of known drugs that act as inhibitors of NF-kappaB signaling and their mechanism of action. Biochem Pharmacol 2010, 79(9):1272-1280.

15. Kasibhatla S, Amarante-Mendes GP, et al: Staining of suspension cells with Hoechst 33258 to detect apoptosis. CSH Protoc 2006, 2006(3) doi:10.1101/ pdb.prot4492.

16. Razzell WE, Khorana HG: Studies on polynucleotides. III. Enzymatic degradation; substrate specificity and properties of snake venom phosphodiesterase. J Biol Chem 1959, 234:2105-2113.

17. Lowry OH, Rosebrough NJ, Farr A, Randall RJ: Protein measurement with the folin phenol reagent. J Biol Chem 1951, 193(1):265-275.

18. Yokogawa M, Yoshimura H, Okura T, Sano M, Tsuji M, Iwasaki M, Hirose H: Chemotherapy of paragonimiasis with bithionol. II. Clinical observations on the treatment with bithionol. Jap J Parasitol 1961, 10:317.

19. Arts HJ, Van Der Zee AG, De Jong S, De Vries EG: Options for modulation of drug resistance in ovarian cancer. Int J Gynecol Cancer 2000, 10(S1):47-52.

20. Deigner HP, Kinscherf R: Modulating apoptosis: current applications and prospects for future drug development. Curr Med Chem 1999, 6:399-414.

21. Kaufmann SH, Earnshaw WC: Induction of apoptosis by cancer chemotherapy. Exp Cell Res 2000, 256:42-49.

22. Kaufmann $\mathrm{SH}$, Gores GJ: Apoptosis in cancer: cause and cure. Bioessays 2000, 22:1007-1017.

23. Zamzami N, Marchetti $P$, Castedo M, Decaudin D, Macho A, Hirsch T, Susin SA, Petit PX, Mignotte B, Kroemer G: Sequential reduction of mitochondrial transmembrane potential and generation of reactive oxygen species in early programmed cell death. J Exp Med 1995, 182(2):367-377.

24. Englert RP, Shacter E: Distinct modes of cell death induced by different reactive oxygen species: amino acyl chloramines mediate hypochlorous acid-induced apoptosis. J Biol Chem 2002, 277:20518-20526.

25. Buolamwini JK: Cell cycle molecular targets in novel anticancer drug discovery. Curr Pharm Des 2000, 6:379-392.

26. McDonald ER, El-Deiry WS: Cell cycle control as a basis for cancer drug development. Int J Oncol 2000, 16:871-886.

27. Sherr CJ, Roberts JM: CDK inhibitors: positive and negative regulators of $\mathrm{G}_{1}$-phase progression. Genes Dev 1999, 13:1501-1512.

28. Goyeneche AA, Caron RW, Telleria CM: Mifepristone inhibits ovarian cancer cell growth in vitro and in vivo. Clin Cancer Res 2007, 13(11):3370-3379. 
29. Jacks T, Weinberg RA: Cell-cycle control and its watchman. Nature (London) 1996, 381:643-644.

30. Sherr CJ: $G_{1}$ phase progression: cycling on cue. Cell 1994, 79:551-555.

31. Sherr CJ, Roberts JM: Inhibitors of mammalian $G_{1}$ cyclin-dependent kinases. Genes Dev 1995, 9:1149-1163.

32. Harper JW, Elledge SJ, Keyomarsi K, Dynlacht B, Tsai LH, Zhang P, Dobrowolski S, Bai C, Connell CL, Swindell E, Fox MP, Wei N: Inhibition of cyclin-dependent kinases by p21. Mol Biol Cell 1995, 6:387-400.

33. Conklin KA: Chemotherapy-associated oxidative stress: Impact on chemotherapeutic effectiveness. Integr Cancer Ther 2004, 3:294-300.

34. Meshkini A, Yazdanparast R: Involvement of oxidative stress in taxolinduced apoptosis in chronic myelogenous leukemia K562 cells. Exp Toxicol Pathol 2012, 64(4):357-365

35. Berndtsson M, Hagg M, Panaretakis T, Havelka AM, Shoshan MC, Linder S: Acute apoptosis by cisplatin requires induction of reactive oxygen species but is not associated with damage to nuclear DNA. Int J of Cancer 2007, 120(1):175-180.

36. Watson AS, Mortensen M, Simon AK: Autophagy in the pathogenesis of myelodysplastic syndrome and acute myeloid leukemia. Cell Cycle 2011, 10(11):1719-1725.

37. Irani K: Oxidant signaling in vascular cell growth, death, and survival: a review of the roles of reactive oxygen species in smooth muscle and endothelial cell mitogenic and apoptotic signaling. Circ Res 2000, 87:179-183.

38. Godwin P, Baird AM, Heavey S, Barr MP, O'Byrne KJ, Gately K: Targeting nuclear factor-kappa B to overcome resistance to chemotherapy. Front Oncol 2013, 3(120):1-10

39. Page CH, Lin J, Jin Y, Castle VP, Nunez G, Huang M, Lin J: Overexpression of Akt/AKT can modulate chemotherapy-induced apoptosis. Anticancer Res 2000, 20:407-416.

40. Lee S, Choi EJ, Jin C, Kim DH: Activation of PI-3 K/Akt pathway by PTEN reduction and PIK3CA mRNA amplification contributes to cisplatin resistance in an ovarian cancer cell line. Gynecol Oncol 2005, 97:26-34.

41. Rokudai S, Fujita N, Kitahara O, Nakamura Y, Tsuruo T: Involvement of FKHR-dependent TRADD expression in chemotherapeutic drug-induced apoptosis. Mol Cell Biol 2002, 22(24):8695-8708.

42. Asselin $E$, Mills GB, Tsang BK: XIA P regulates Akt activity and caspase3-dependent cleavage during cisplatin-induced apoptosis in human ovarian epithelial cancer cells. Cancer Res 2001, 61(5):1862-1868.

43. Bharti AC, Aggarwal BB: Chemopreventive agents induce suppression of nuclear factor-kappaB leading to chemo sensitization. Ann N Y Acad Sci 2002, 973:392-395.

44. Wang CY, Cusack JC Jr, Liu R, Baldwin AS Jr: Control of inducible chemoresistance: enhanced anti-tumor therapy through increased apoptosis by inhibition of NF-KB. Nat Med 1999, 5:412-417.

45. Cusack JC, Liu R, Baldwin AS: NF-kB and chemoresistance: potentiation of cancer drugs via inhibition of NF-KB. Drug Resist Updat 1999, 2:271-273.

46. Toledano MB, Leonard WJ: Modulation of transcription factor NF-kappa B binding activity by oxidation-reduction in vitro. Proc Natl Acad Sci USA 1991, 88(10):4328-4332.

47. Liu J, Yoshida Y, Yamashita U: DNA-binding activity of NF-kappaB and phosphorylation of p65 are induced by $\mathrm{N}$-acetylcysteine through phosphatidylinositol (PI) 3-kinase. Mol Immunol 2008, 45(15):3984-3989.

48. Vermeulen L, De Wilde G, Notebaert S, Vanden Berghe W, Haegeman G: Regulation of the transcriptional activity of the nuclear factor-kappaB p65 subunit. Biochem Pharmacol 2002, 64(5-6):963-970.

49. Cheng JQ, Jiang X, Fraser M, Li M, Dan HC, Sun M, Tsang BK: Role of $X$-linked inhibitor of apoptosis protein in chemoresistance in ovarian cancer: possible involvement of the phosphoinositide-3 kinase/Akt pathway. Drug Resist Updat 2002, 5(3-4):131-146.

50. Witham J, Valenti MR, De-Haven-Brandon AK, Vidot S, Eccles SA, Kaye SB, Richardson A: The Bcl-2/Bcl-XL family inhibitor ABT-737 sensitizes ovarian cancer cells to carboplatin. Clin Cancer Res 2007, 13(23):7191-7198.

51. Eliopoulos AG, Kerr DJ, Herod J, Hodgkins L, Krajewski S, Reed JC, Young LS: The control of apoptosis and drug resistance in ovarian cancer: influence of p53 and Bcl-2. Oncogene 1995, 11:1217-1228.

52. Herod JO, Eliopoulos AG, Warwick J, Niedobitek G, Young LS, Kerr DJ: The prognostic significance of $\mathrm{Bcl}-2$ and $\mathrm{p} 53$ expression in ovarian carcinoma. Cancer Res 1996, 56:2178-2184.

53. Nam SW, Clair T, Campo CK, Lee HY, Liotta LA, Stracke ML: Autotaxin (ATX), a potent tumor mitogen, augments invasive and metastatic potential of ras-transformed cells. Oncogene 2000, 19:241-247.
54. Nam SW, Clair T, Kim YS, et al: Autotaxin (NPP-2), a metastasis-enhancing motogen, is an angiogenic factor. Cancer Res 2001, 61:6938-6944.

55. Vidot S, Witham J, Agarwal R, Greenhough S, Bamrah HS, Tigyi GJ, Kaye SB, Richardson A: Autotaxin delays apoptosis induced by carboplatin in ovarian cancer cells. Cell Signal 2010, 22(6):926-935.

56. Xu Y, Gaudette DC, Boynton JD, et al: Characterization of an ovarian cancer activating factor in ascites from ovarian cancer patients. Clin Cancer Res 1995, 1:1223-1232.

57. Xu Y, Xiao YJ, Zhu K, Baudhuin LM, Lu J, Hong G, Kim KS, Cristina KL, Song $L$, Elson P, Markman M, Belinson J: Unfolding the pathophysiological role of bioactive lysophospholipids. Curr Drug Targets Immune Endocr Metabol Disord 2003, 3:23-32

58. Sengupta S, Kim KS, Berk MP, Oates R, Escobar P, Belinson J, Li W, Lindner DJ, Williams B, Xu Y: Lysophosphatidic acid downregulates tissue inhibitor of metalloproteinases, which are negatively involved in lysophosphatidic acid-induced cell invasion. Oncogene 2007, 26:2894-2901.

59. Brindley DN, Pilquil C: Lipid phosphate phosphatases and signaling. J Lipid Res 2009, 50:S225-S230.

60. Ye X, Ishii I, Kingsbury MA, Chun J: Lysophosphatidic acid as a novel cell survival/apoptotic factor. Biochim Biophys Acta 2002, 1585:108-113.

61. Tigyi G, Parrill AL: Molecular mechanisms of lysophosphatidic acid action. Prog Lipid Res 2003, 42:498-526.

62. Awada R, Rondeau P, Grès S, Saulnier-Blache JS, Lefebvre d'Hellencourt C, Bourdon E: Autotaxin protects microglial cells against oxidative stress. Free Radic Biol Med 2012, 52(2):516-526.

doi:10.1186/1471-2407-14-61

Cite this article as: Ayyagari and Brard: Bithionol inhibits ovarian cancer cell growth In Vitro - studies on mechanism(s) of action. BMC Cancer 2014 14:61.

\section{Submit your next manuscript to BioMed Central and take full advantage of:}

- Convenient online submission

- Thorough peer review

- No space constraints or color figure charges

- Immediate publication on acceptance

- Inclusion in PubMed, CAS, Scopus and Google Scholar

- Research which is freely available for redistribution 